\title{
Perubahan Motif Wisata Pada Era Industri 4.0 (Studi Kasus: Sam Poo Kong Temple, Semarang)
}

\author{
I D Murtadha Isnan ${ }^{1}$, Pramesi Lokaprasidha ${ }^{2}$ \\ islah.ide@gmail.com ${ }^{1}$,pramesi.fisip@unej.ac.id ${ }^{2}$
}

\begin{abstract}
The industrial revolution 4.0 is not only a technological development from the previous era, but it is also able to turn off conventional business. The industrial revolution 4.0 will also bring the distance between producers and their target markets to a close relation. Digital marketing is a way to promote products/brands through internet. Through advertising on social media or e-commerce. In the world of tourism, motivation is one important factor for tourists in making decisions about tourist destinations to be visited. Tourists will have perceptions of possible tourist destinations. The current motivation of tourists to Sam Poo Kong Temple has begun to change, which once had a religious motive but now has changed to a motive for social status. Sam Poo Kong temple which has spiritual and cultural values especially for Confucians changes in line with the times in the millennial era. Orientation on the use of social media can change the visiting trend and support psychological needs in terms of popularity on social media pages.
\end{abstract}

Keyword: Digital Marketing, Tourists Motive, The industrial revolution 4.0, Sam Poo Kong Temple

\begin{abstract}
Abstrak
Revolusi industri 4.0 tidak hanya merupakan pengembangan teknologi dari era sebelumnya, namun hal ini juga mampu mematikan bisnis konvesional. Revolusi industri 4.0 juga akan mendekatkan jarak antara produsen dan taget marketnya. Digital marketing ialah suatu cara untuk mempromosikan produk/brand melalui media internet. Bisa melalui iklan di sosial media atau e-commerce. Dalam dunia pariwisata, motivasi adalah salah satu faktor penting untuk wisatawan dalam mengambil keputusan mengenai destinasi wisata yang akan dikunjungi. Wisatawan akan mempunyai persepsi pada daerah tujuan wisata yang memungkinkan. Motivasi wisatawan saat ini ke Klenteng Sam Poo Kong sudah mulai berubah, yang dahulu memiliki motif religi namun saat ini berubah menjadi motif status sosial. Klenteng Sam Poo Kong yang memiliki nilai spiritual dan budaya khususnya bagi umat Konghucu berubah sejalan dengan perkembangan zaman di era milenial. Orientasi pada penggunaan sosial media dapat merubah tren kunjungan serta menunjang kebutuhan psikologi dalam hal popularitas pada laman media sosial.
\end{abstract}

Kata Kunci: Digital marketing, Motif wisata, Revolusi industri 4.0, Klenteng Sam Poo Kong

\footnotetext{
1 Sekolah Tinggi Pariwisata Ambarrukmo Yogyakarta

2 Universitas Jember
} 


\section{Pendahuluan}

Kebudayaan berasal dari kata sansekerta buddayah, yang merupakan bentuk jamak dari buddhi, yang berarti budi atau akal. Dengan demikian, kebudayaan berarti hal-hal yang bersangkutan dengan akal. Definisi lain dikemukakan oleh Linton dalam buku: The Cultural Background of Personality, bahwa kebudayaan adalah konfigurasi dari tingkah laku yang dipelajari dari hasil tingkah laku, yang unsur-unsur pembentukannya didukung dan diteruskan oleh anggota masyarakat tertentu, (Sukidin, 2005).

Pada era industri 4.0 Teknologi informasi dan komunikasi (TIK) merupakan sarana yang membantu dalam kehidupan di berbagai bidang termasuk dalam dunia pariwisata. Di zaman sekarang menjadi suatu kebutuhan mendasar dalam sebuah orginasasi, perusahaan, instansi pemerintah dan instansi pendidikan. Peranan TIK dalam dunia pariwisata sebagai sarana dan prasarana dalam mempromosikan pariwisata yang sering kita dengar secara elektronik dengan nama digital marketing. Banyak destinasi wisata saat ini dikenal oleh calon wisatawan melalui media sosial yang merupakan bagian kecil dari TIK, persebaran informasi melalui media sosial dirasa sangat meyakinkan dan cepat. Hal tersebut berpengaruh pada motif wisatawan dalam melakukan perjalanan wisata yang sudah menjadi bagian dari kebutuhan saat ini.

Hubungan era industri 4.0 dengan digital marketing sangat berhubungan dengan prinsip yang terintegrasi satu sama lain. Revolusi industri 4.0 diantaranya (Hasmaidi.com, 2018):

1. Revolusi Industri 1, pertama kali terjadi pasca ditemukan mesin uap, sehingga terjadinya perkembangan dan pertumbuhan yang besar dalam mesinmesin industri di Inggris pada Tahun 1764. revolusi ini berdampak pada sektor pertanian dan manufaktur / industri terutama industri tekstil dan turunannya.

2. Revolusi Industri ke 2 adalah diawal abad ke 19, dimana terjadinya perbaikan pada sisi proses, dimana proses dalam skala besar (mass production) dikenal juga berkat inovasi dari ford. penemuan pada masa ini lebih kearah listrik dan transportasi, kombinasi cara produksi dan perkembangannya ini berpengaruh pada teknologi terutama untuk industri besi, mesin-mesin, minyak, kimia, kendaraan dan lain-lain.

3. Revolusi Industri Ke 3, dikenal masa otomasi, pasca perang dunia, ditandai dengan penggunaan teknologi tinggi otomatis, menggunakan elektronik dan teknologi informasi. inilah yang berlangsung sampai hari ini. dimana mesin dan peningkatan kapasitas produksi dan software menjadi pendukung utama pada proses manufaktur.

4. Revolusi Industri ke 4 yang saat ini dihadapai menjelaskan bahwa mesin dan kapasitas produksi saja, tidak cukup membuat pertumbuhan bagi suatu negara. Seiring dengan hal itu perkembangan teknologi informasi saat ini, software dan hardware serta pesatnya perkembangan penggunaan internet oleh forum ekonomi dunia.

World Economic gelombang perubahan saat ini, dengan gelombang perubahan yang melibatkan sejumlah gabungan teknologi perangkat dan software yang menyatukan hal fisik dan digital, yang memiliki dampak luas, jauh lebih besar 
dibadingkan revolusi industri sebelumnya, teknologi ini diyakini akan mampu meningkatkan produktivitas hingga $30 \%$. Revolusi industri 4.0 ini tidak hanya merupakan pengembangan dari teknologi sebelumnya, namun bakal mampu mematikan bisnis konvesional, akibat dunia yang sudah tersambung dengan dunia internet dan teknologi informasi saat ini. Revolusi industri 4.0 ini akan memberikan efek meperdekat jarak antara produsen dan taget marketnya. yang menjadi penggerak terbesar dari transformasi digital adalah teknologi informasi. TIK yang sudah dimanfaatkan dalam semua bidang. TIK mampu mengantarkan produsen dengan cepat kepada target market, dan memudahkannya untuk mendapatkan pembiayaan, dan dapat bertumbuh dengan cepat dengan pengembangkan jangkauan produk tanpa batas dengan dukungan kecepatan teknologi yang diakses. Namun bagaimanapun manusia adalah komponen terpenting "Man Behind The Gun" jadi pengembangan sumber daya manusia sangat penting. pada zamannya saat ini , sumber daya manusia yang terlibat langsung saat ini adalah Gen Y yang lahir antara 1981-1994 dan generasi Z lahir 1995-2010 yang memang merupakan pelopor revolusi industri 4.0. Industri 4.0 adalah nama tren otomatis dan pertukaran data terkini dalam teknologi.

Dalam penelitian (case study) ini, Sam Poo Kong Temple menjadi objek yang sudah tidak asing lagi bagi wisatawan domestik maupun mancanegara. Terletak di ibu kota provinsi Jawa Tengah menjadi nilai plus serta posisi yang strategis membuat destinasi ini semakin dikenal oleh khalayak ramai. Klenteng yang dahulu hanya menjadi tempat ibadah umat Konghucu, saat ini sudah banyak berubah fungsi menjadi destinasi wisata untuk swafoto dan meningkatkan prestise wisatawan itu sendiri. Perubahan atau pergeseran nilai ini menjadi salah satu motif wisatawan di era digital 4.0 saat ini. Perkembangan sosial media juga menjadi salah satu faktor meningkatnya kunjungan wisatawan pada destinasi wisata akhir-akhir ini. Sosial media menjadi media pemasaran paling ampuh untuk meningkatkan jumlah kunjungan dalam waktu yang singkat.

Industri 4.0 di bidang pariwisata menekankan pada Tourism and The Digital Transformation atau Pariwisata dan Transformasi Digital. Penelitian ini akan membahas mengenai perkembangan salah satu objek wisata budaya (Sam Poo Kong Semarang) dalam era digital marketing bidang pariwisata yang dilatar belakangi oleh industri 4.0 dan perilaku generasi $\mathrm{Y}$ dan Z.

\section{Landasan Teori}

Pengertian digital marketing menurut sumber (redtreeasia.com, 2018) adalah suatu usaha untuk melakukan pemasaran sebuah brand atau produk melalui dunia digital atau internet. Tujuannya ialah untuk menjangkau konsumen maupun calon konsumen secara cepat dan tepat waktu. Digital marketing ialah suatu cara untuk mempromosikan produk/brand tertentu melalui media internet. Bisa melalui iklan di internet, facebook, youtube, ataupun media sosial lainnya. Hal tersebut sangat berpengaruh atas keberadaan objek wisata dalam perkembangannya saat ini, objek wisata budaya Klenteng Sam Poo Kong salah satunya yang mendapatkan dampak dari perkembangan digital marketing saat ini.

Menurut Koentjaraningrat (2002) mengatakan, bahwa menurut ilmu antropologi kebudayaan adalah keseluruhan 
sistem gagasan, tindakan dan hasil karya manusia dalam rangka kehidupan masyarakat yang dijadikan milik diri manusia dengan belajar. Dia membagi kebudayaan atas 7 unsur: sistem religi, sistem organisasi kemasyarakatan, sistem pengetahuan, sistem mata pencaharian hidup, sistem teknologi dan peralatan bahasa dan kesenian. Kesemua unsur budaya tersebut terwujud dalam bentuk sistem budaya atau adat-istiadat (kompleks budaya, tema budaya, gagasan), sistem sosial (aktivitas sosial, kompleks sosial, pola sosial, tindakan), dan unsur-unsur kebudayaan fisik (benda kebudayaan).

1. Sistem Religi

Sistem religi meliputi kepercayaan, nilai, pandangan hidup, komunikasi keagamaan dan upacara keagamaan. Definisi kepercayaan mengacu kepada pendapat Fishbein dan Azjen (dalam Soekanto, 2007), yang menyebutkan pengertian kepercayaan atau keyakinan dengan kata "belief", yang memiliki pengertian sebagai inti dari setiap perilaku manusia. Aspek kepercayaan tersebut merupakan acuan bagi seseorang untuk menentukan persepsi terhadap sesuatu objek. Kepercayaan membentuk pengalaman, baik pengalaman pribadi maupun pengalaman sosial.

2. Sistem kemasyarakatan atau organisasi Menurut Syani, (1995), Sistem Organisasi dan Kemasyarakatan sosial yang meliputi: kekerabatan, organisasi politik, norma atau hukum, perkawinan, kenegaraan, kesatuan hidup dan perkumpulan. Sistem organisasi adalah bagian kebudayaan yang berisikan semua yang telah dipelajari yang memungkinkan bagi manusia mengkoordinasikan perilakunya secara efektif dengan tindakan-tindakan orang lain.

3. Sistem Pengetahuan Spradlye (dalam Kalangie, 1994) itu bukanlah sesuatu yang bisa kelihatan secara nyata, melainkan tersembunyi dari pandangan, namun memainkan peranan yang sangat penting bagi manusia dalam menentukan perilakunya. Pengetahuan budaya yang diformulasikan dengan beragam ungkapan tradisional itu sekaligus juga merupakan gambaran dari nilai - nilai budaya yang mereka hayati.

4. Sistem Mata Pencaharian Hidup Menurut Koentrajaningrat, (2002), Sistem mata pencaharian hidup merupakan produk dari manusia sebagai homo economicus yang mejadikan kehidupan manusia terus meningkat. Dalam tingkat sebagai food gathering, kehidupan manusia sama dengan hewan. Tetapi dalam tingkat food producing terjadi kemajuan yang pesat. Setelah bercocok tanam, kemudian beternak yang terus meningkat (rising demand) yang kadang-kadang serakah. Sistem mata pencaharian hidup atau sistem ekonomi meliputi jenis pekerjaan dan penghasilan.

5. Sistem Teknologi dan Peralatan Teknologi dan peralatan kesehatan adalah sarana prasarana yang diperlukan untuk tindakan pelayanan, meliputi: ketersediaan, keterjangkauan dan kualitas alat. Hal ini tidak adanya perbedaan diantara masyarakatnya yang multi etnis, mereka hidup berdampingan dan saling melengkapi satu dengan yang lainnya.

6. Bahasa

Bahasa adalah alat atau perwujudan budaya yang digunakan manusia untuk 
saling berkomunikasi atau berhubungan, baik lewat tulisan, lisan, ataupun gerakan (bahasa isyarat), dengan tujuan menyampaikan maksud hati atau kemauan kepada lawan bicaranya atau orang lain. Melalui bahasa, manusia dapat menyesuaikan diri dengan adat istiadat, tingkah laku, tata krama masyarakat, dan sekaligus mudah membaurkan dirinya dengan segala bentuk masyarakat. Bahasa memiliki beberapa fungsi yang dapat dibagi menjadi fungsi umum dan fungsi khusus.

7. Kesenian

Menurut Koentrajaningrat (2002), Kesenian mengacu pada nilai keindahan (estetika) yang berasal dari ekspresi hasrat manusia akan keindahan yang dinikmati dengan mata ataupun telinga. Sebagai makhluk yang mempunyai cita rasa tinggi, manusia menghasilkan berbagai corak kesenian mulai dari yang sederhana hingga perwujudan kesenian yang kompleks. Kesenian yang meliputi: seni patunga tau pahat, seni rupa, seni gerak, lukis, gambar, rias, vocal, musik atau seni suara, bangunan, kesusastraan, dan drama.

Pariwisata budaya merupakan salah satu sektor wisata yang banyak dikembangkan oleh pemerintah daerah akhir-akhir ini. Menurut Nafila (2013), bahwa pariwisata budaya adalah salah satu jenis pariwisata yang menjadikan budaya sebagai daya tarik utama. Dimana di dalam pariwisata budaya ini wisatawan akan diapndu untuk disamping mengenali sekaligus memahami budaya dan kearifan pada komunitas lokal tersebut. Di samping itu, pengunjung akan dimanjakan dengan pemandangan, tempat-tempat bersejarah sekaligus museum, representasi nilai dan sistem hidup masyarakat lokal, seni (baik seni pertunjukan atau pun seni lainnya), serta kuliner khas dari masyarakat asli atau masyarakat lokal yang bersangkutan. Sedangkan Goeldner mengemukakan dalam (Nafila, 2013: 1) bahwa pariwisata budaya mencakup semua aspek dalam perjalanan untuk saling mempelajari gaya hidup maupun pemikiran. Definisi ini lebih mengarah pada tujuan pengunjung atau wisatawan mengunjungi wisata budaya lebih pada untuk memahami hakikat dan membandingkannya dengan kondisi budaya yang dimilikinya sebagai sebuah pemahaman baru, tentunya disamping adanya nilai estetika yang terkandung di dalamnya.

Motivasi wisatawan adalah dorongan yang mempengaruhi seseorang untuk melakukan suatu perjalanan wisata bisa dibagi menjadi empat macam, yaitu:

1. Physical / physiological motivation / motivasi yang mempunyai sifat fisik / fisiologis. Ex : Relaksasi, kesehatan, kenyamanan, berpartisipasi dalam kegiatan olahraga, bersantai, dan yang berhubungan dengan sifat fisik lain.

2. Cultural motivation atau motivasi budaya, adalah keinginan untuk mengetahui budaya, adat, tradisi, dan kesenian di daerah lain. Ex : Objek peninggalan budaya atau bangunan yang bersejarah.

3. Social motivation / interpersonal motivation / motivasi yang mempunyai sifat sosial Ex : mengunjungi teman dan keluarga, menemui mitra kerja, melakukan hal yang dianggap mendatangkan gengsi, seperti nilai prestise, melakukan ziarah, dan melakukan pelarian dari situasi-situasi yang membosankan.

4. Fantasy motivation atau motivasi karena fantasi, merupakan adanya fantasi 
bahwa di daerah lain, seseorang akan mampu lepas dari rutinitas keseharian yang menjemukan, dan egoenhancement yang memberi kepuasan psikologis. Hal seperti itu juga disebut dengan status and prestige motivation.

\section{Pembahasan}

Menurut Yoeti, (1996) Pariwisata merupakan salah satu sektor pembangunan yang saat ini sedang digalakkan oleh pemerintah. Tujuan pengembangan pariwisata di Indonesia terlihat dengan jelas dalam Instruksi Presiden Republik Indonesia Nomor 9 Tahun 1969, khususnya Bab II Pasal 3, yang menyebutkan usaha pengembangan pariwisata di Indonesia yang fokus pada pengembangan "industri pariwisata" dan merupakan bagian dari usaha pengembangan dan pembangunan serta kesejahtraan masyarakat dan Negara. Beberapa jenis objek wisata yang ada di Indonesia, antara lain:

1. Wisata Alam.

Indonesia memiliki kawasan terumbu karang terkaya di Dunia dengan lebih dari $18 \%$ terumbu karang di dunia. Serta lebih dari 3000 species ikan, 590 jenis karang batu dan banyak lagi objek wisata yang sangat menarik. Seperti Raja Ampat di Papua Barat, Teluk Kiluan di Lampung dan Pulau Derawan

2. Wisata Belanja.

Wisata di Indonesia terbagi dengan pusat belanja modern dan tradisional. Contohnya pusat belanja modern seperti mall dan setiap tahun selalu ada Jakarta Great Sale yang memberikan diskon secara besar- besaran. Sedangkan pasar tradisional seperti Pasar Beringharjo di Jogjakarta,

3. Wisata Budaya
Berdasarkan data sensus 2010, Indonesia terdiri dari 1.128 suku bangsa. Sehingga Indonesia terkenal dengan kayanya budaya tradisional, misalnya sendratari Ramayana yang sering di pentaskan di Candi Prambanan. Tari Kecak, Tari Legong di Bali. Serta tari Piring dari Padang.

4. Wisata Religi

Wisata Religi di Indonesia cukup banyak, misalnya Wisata Religi ke makam Walisongo, atau kebeberapa peninggalan sejarah yang menggambarkan agama Tiong Hoa salah satunya adalah Klenteng Sam Poo Kong.

Disebut Gedung Batu karena bentuknya merupakan gua batu besar yang berada di sebuah bukit batu. Orang Indonesia keturanan China ( Tiong Hoa) untuk mengenang Zheng He atau Cheng Ho dan teman temannya maka dibangunlah sebuah kelenteng. Sekarang tempat tersebut dijadikan tempat peringatan dan tempat pemujaan atau bersembahyang serta tempat untuk berziarah. Untuk keperluan tersebut, di dalam gua batu itu diletakan sebuah altar, serta patung-patung Sam Po Tay Djien. Meskipun Laksamana Cheng Ho adalah seorang muslim, tetapi mereka menganggapnya sebagai dewa. Hal ini dapat dimaklumi mengingat agama Kong $\mathrm{Hu} \mathrm{Cu}$ atau Tao menganggap orang yang sudah meninggal dapat memberikan pertolongan kepada mereka.

\section{Daya Tarik Klenteng Sam Poo Kong}

Menurut cerita, Laksamana Zheng He atau Cheng Ho sedang berlayar melewati laut jawa, namun saat melintasi laut jawa, banyak awak kapalnya yang jatuh sakit, kemudian ia memerintahkan untuk 
membuang sauh. Kemudian merapat ke pantai utara semarang untuk berlindung di sebuah Goa dan mendirikan sebuah masjid (belum ada bukti yg konkrit) di tepi pantai yang sekarang telah berubah fungsi menjadi kelenteng. Bangunan itu sekarang telah berada di tengah kota Semarang di akibatkan pantai utara jawa selalu mengalami proses pendangkalan yang diakibatkan adanya proses sedimentasi sehingga lambat-laun daratan akan semakin bertambah luas kearah utara. Konon, setelah Zheng He atau Cheng Ho meninggalkan tempat tersebut karena ia harus melanjutkan pelayarannya, banyak awak kapalnya yang tinggal di desa Simongan dan kawin dengan penduduk setempat. Mereka bersawah dan berladang di tempat itu. Zheng $\mathrm{He}$ atau Cheng Ho memberikan pelajaran bercocoktanam serta menyebarkan ajaran-ajaran Islam, di Kelenteng ini juga terdapat Makam Seorang Juru Mudi dari Kapal Laksamana Cheng Ho.

Adapun beberapa daya tarik yang ada di Klenteng Sam Poo Kong sebagai berikut:

1. Tempat Pemujaan Klenteng Besar Tempat utama Klenteng Sam Poo Kong dan Goa Sam Poo. Tempat ini merupakan pusat dari seluruh kegiatan didalam Komplek Klenteng Sam Poo Kong. Pada tempat ini juga dibangun sebuah Goa Sam Poo Baru yang didalamnya terdapat patung Sam Poo Tay Djien bersama dua pengawalnya Lauw Im dan Thio Kee yang juga dihormati atas jasa-jasanya. Di bawah Klnteng Utama terdapat Goa Sam Poo Lama yang sampai sekarang tetap dijaga dan dilestarikan. Didalam Goa tersebut terdapat sumber air yang tidak pernah kering meskipun musim kemarau panjang. Para umat yang datang ke tempat tersebut untuk bersembahyang dan mengambila air dari mata air tersebut karena menurut kepercayaannya air tersebut memiliki khasiat.

2. Tempat Pemujaan Dewa Bumi (Tho Tee Kong)

Disini umat memanjatkan ucapan terima kasih dan rasa syukur kepada dewa bumi karena telah diberikan tanah yang subur, panen melimpah dan kekayaan alam yang beraneka ragam.

3. Tempat Pemujaan Makam Kyai Juru Mudi Menurut cerita, Wang Jing Hong merupakan juru mudi dalam pelayaran Armada Zheng $\mathrm{He}$ atau Chen Ho (Cheng Ho). Ketika tiba di Pantai Utara Jawa Wang Jing Hong mendadak sakit keras dan tidak bisa melanjutkan perjalanan. Untuk menghormati Laksamana Cheng Ho, Wang Jing Hong mendirikan patung di Goa Sam Poo. Wang Jing Hong meninggal dunia pada usia 87 dan dimakamkan disamping Klenteng Sam Poo Kong.

4. Tempat Pemujaan Mbah Kyai Jangkar Jangkar besar ini merupakan lambang yang mewakili kapal-kapal armada Cheng Ho dan digunakan sebagai alat konsentrasi dalam sembahyang dan semedi.

5. Pohon Rantai

Dalam Klenteng Sam Poo Kong juga terdapat pohon unik yang batangnya menyerupai rantai atau kepang rambut. Konon, batang pohon yang membentuk rantai ini digunakan sebagai pengganti tambang kapal dalam keaadaan darurat, "rantai" ini tampak menjuntai dan melilit-lilit bisa kita lihat di tempat Pemujaan Mbah Kyai Jangkar.

6. Gambar Relief

Relief ini menggambarkan beberapa sejarah perjalanan Laksamana Cheng Ho yang terdiri dari 10 diorama yang saling bersambung. Cerita dalam relief 
disajikan dalam tiga bahasa, yaitu Indonesia, Inggris, dan Mandarin.

Dari segala bentuk Kawasan Komplek Klenteng Sam Poo Kong yang menarik untuk dikunjungi berpengaruh juga pada motivasi wisatawan untuk berkunjung. Sam Poo Kong sebagai Kelenteng merupakan warisan budaya dalam bentuk arsitektur dengan nilai-nilai yang terkandung didalamnya sebagai tempat ibadah umat Tiong Hoa. Sam Poo Kong mulai dikenal sebagai Kawasan yang dikunjungi wisatawan semenjak dibuka untuk umum, alasan tersebut diambil karena Sam Poo Kong sendiri merupakan peninggalan budaya yang mengandung sejarah dalam perkembangannya dan hal tersebut yang mendasari untuk dibuka untuk umum sebagai tempat belajar, berwisata budaya dengan mengenalkan kebudayaan yang ada di Sam Poo Kong dan sekitarnya. Nilai-nilai yang ada didalamnya selain menjadi identitas kaum atau umat Tiong Hoa juga menjadi salah satu daya Tarik yang banyak masyarakat atau wisatawan yang ingin tau.

Dari semua daya tarik yang ada di Klenteng Sam Poo Kong Semarang jika disesuaikan dengan bagaimana cara untuk mengembangkan menjadi salah satu destinasi yang menjadi keharusan untuk dikunjungi jika berada di Semarang adalah dengan memanfaatkan segala upaya promosi sesuai dengan kebutuhan wisatawan saat ini, adapun beberapa upaya jika disesuaikan dengan era sekarang yaitu era industri 4.0 adalah dengan memanfaatkan sistem digitalisasi yang sesuai dengan perkembangan kebiasaan calon wisatawan sasaran yaitu kaum milenial atau wisatawan dengan rentan umur 20-40 tahun. Era digitalisasi sangat menunjang dalam proses promosi suatu kawasan destinasi yang memiliki daya tarik wisata, penggunaan sosial media yang semakin tinggi juga menjadi peluang dalam pemanfaatannya sebgai media promosi dikarenakan sasaran calon wisatawan yang dituju adalah kaum milenial yang tidak terlepas dari sosial media.

Keberadaan Klenteng Sam Poo Kong saat ini yang mulai meroket popularitasnya sebagai objek daya tarik wisata di Semarang didukung oleh promosi yang dilakukan secara massive akan tetapi sangat berpengaruh yakni dengan penggunaan media sosial. Perkembangan objek daya tarik wisata Sam Poo Kong Semarang saat ini telah menjadi salah satu destinasi wajib dikunjungi jika ke Semarang.

\section{Bentuk Motivasi Wisatawan}

Bentuk motivasi wisatawan saat ini dalam melakukan perjalan wisata utamanya ke Klenteng Sam Poo Kong saat ini sudah mulai berubah dari bentuk Klenteng yang sebenarnya merupakan nilai dari budaya yang seharusnya dipelajari nilainya akan tetapi berubah sejalan dengan perkembangan zaman di era milenial yang trend dari kunjungannya berorientasi pada penggunaan sosial media, menunjang kebutuhan psikologi dalam hal popularitas di media sosial. Hal tersebut yang menjadikan Klenteng Sam Poo Kong sebagai tujuan wisata wajib dikunjungi di Semarang, akan tetapi tidak dalam konteks menikmati nilai dari budaya namun dalam memenuhi kebutuhan updating sosial media yang menjadi salah satu acuan peningkatan kualitas hidup di era saat ini. Karenanya nilai dari standar hidup di era 4.0 dipengaruhi dari sejauh mana dan seberapa banyak tempat yang telah dikunjungi oleh seseorang dengan bukti unggahan di media sosial. Saat ini, trend motivasi kunjungan 
wisatawan kaum milenial tidak lagi berorientasi pada nilai yang terdapat di objek yang dikunjungi akan tetapi seberapa bagus tempat tersebut untuk diunggah di media sosial.

\section{Kesimpulan}

Pemanfaatan digital marketing di industri 4.0 sangat berperan dalam meningkatkan promosi pariwisata pada generasi Y dan Z. Digital marketing merupakan suatu keharusan karena generasi ini yang sering digunakan baik disadari maupun tidak. Aplikasi digital marketing yang akan digunakan diantaranya website, media sosial, online advertising, web forum dan mobile aplikasi. Dengan adanya digital marketing kedepannya akan memudahkan wisatan untuk melakukan perjalanan wisata dengan mudah dan praktis. Pemanfaatan digital marketing di era revolusi industri 4.0 pada dunia pariwisata tidak hanya mengubah paradigma industri, namun juga dalam hal pekerjaan, cara berkomunikasi, berbelanja, bertransaksi, hingga gaya hidup. Salah satu perubahan yang tampak nyata adalah tren motivasi wisatawan dalam berkunjung ke suatu tempat atau objek wisata tidak lagi berorientasi pada nilai estetika yang terdapat di objek tersebut melainkan berorientasi hanya pada kebutuhan psikologi wisatawan. Era milenial saat ini sangat tergantung pada popularitas yang dipengaruhi hasil unggahan media sosial. Perubahan inilah yang menjadi tren saat ini, yang semula suatu objek dinilai dari hasil yang ada dalam setiap objek berubah seiring perkembangan zaman, nilai-nilai mulai tidak dihiraukan dan tidak menjadi permasalahan. Saat ini wisatawan khususnya generasi milenial hanya berorientasi pada hasil unggahan yang akan menarik netizen memberikan respon melalui media sosial.

\section{Daftar Pustaka}

Digitalmarketingpariwisata.com. (2018). No Title. Retrieved from digitalmarketingpariwisata.com

Hasmaidi.com. (2018). No Title. Retrieved September 10, 2018, from https://hasmaidi.com/pemahamanrevolusi-industri-4

Kalangie. 1994. Kebudayaan dan kesehatan. Jakarta: Kesaint Blanc.

Koentjaraningrat. 2002. Pengantar Ilmu Antropologi. Jakarta: PT. Rineka Cipta.

Redtreeasia.com. (2018). No Title. Retrieved September 29, 2018, from http://redtreeasia.com/info/apa-itudigital-marketing-pengertian-dankonsep- dasarnya

Soekanto Soerjono. 2007. Sosiologi suatu pengantar. Jakarta : PT Raja Grafindo Persada.

Sukidin dan Munir. 2005. Metode Penelitian. Surabaya: Insan Cendekia.

Nafila, O. 2013. Peran Komuninas Kreatif dalam Pengembangan Pariwisata Budaya di Situs Megalithikum Gunung Padang. Jurnal Perencanaan Wilayah dan Kota, Vol. 24, No. 1, April 2013.

Syani, Abdul. 1995. Sosiologi dan Perubahan Masyarakat. Bandar lampung: Pustaka Jaya. Unila

Yoeti, O. A. (1996). Pengantar Ilmu Pariwisata. Bandung: Penenbit Airlangga 
